\title{
Parameters and characteristics governing cellular internalization and trans-barrier trafficking of nanostructures
}

This article was published in the following Dove Press journal:

International Journal of Nanomedicine

18 March 2015

Number of times this article has been viewed

\author{
Karmani Murugan \\ Yahya E Choonara \\ Pradeep Kumar \\ Divya Bijukumar \\ Lisa C du Toit \\ Viness Pillay
}

Wits Advanced Drug Delivery Platform Research Unit, Department of Pharmacy and Pharmacology, School of Therapeutic Sciences, Faculty of Health Sciences, University of the Witwatersrand, Johannesburg, South Africa
Correspondence: Viness Pillay Department of Pharmacy and Pharmacology, School of Therapeutic Sciences, Faculty of Health Sciences, University of the Witwatersrand, 7 York Road, Parktown, Johannesburg, South Africa

Tel +27 II 7172274

Fax +27 I I 6424355

Email viness.pillay@wits.ac.za

\begin{abstract}
Cellular internalization and trans-barrier transport of nanoparticles can be manipulated on the basis of the physicochemical and mechanical characteristics of nanoparticles. Research has shown that these factors significantly influence the uptake of nanoparticles. Dictating these characteristics allows for the control of the rate and extent of cellular uptake, as well as delivering the drug-loaded nanosystem intra-cellularly, which is imperative for drugs that require a specific cellular level to exert their effects. Additionally, physicochemical characteristics of the nanoparticles should be optimal for the nanosystem to bypass the natural restricting phenomena of the body and act therapeutically at the targeted site. The factors at the focal point of emerging smart nanomedicines include nanoparticle size, surface charge, shape, hydrophobicity, surface chemistry, and even protein and ligand conjugates. Hence, this review discusses the mechanism of internalization of nanoparticles and ideal nanoparticle characteristics that allow them to evade the biological barriers in order to achieve optimal cellular uptake in different organ systems. Identifying these parameters assists with the progression of nanomedicine as an outstanding vector of pharmaceuticals.
\end{abstract}

Keywords: nanoparticles, transport mechanisms, cellular uptake, size, shape, charge

\section{Introduction}

The emergence of nanomedicine provides a strategic, therapeutic tool that aims to increase drug targeting to site-specific areas within the body. Nanoparticle (NP) research has identified the crossing of mucosal barriers and cellular uptake to support NP utilization, as well as NP surface properties that affect these phenomena. ${ }^{1}$ In the design of NPs for biological use, significant factors to overcome limitations associated with insufficient drug delivery to targeted sites include NP size, surface charge, shape, chemical composition, and stability. ${ }^{2,3}$ Manipulating these pertinent NP characteristics may facilitate various applications and enhanced cellular and trans-barrier internalization of NPs into the target sites. These sites innately have a biological barrier to prevent the entry of foreign objects, thus resulting in decreased drug concentrations at the intended site. Ideally, nanomedicine should circumvent the biological barriers and enhance drug targeting and NP uptake. ${ }^{4}$

Figure 1 illustrates different transport mechanisms across and into the biological membrane for the internalization of NPs; key terms related to NP internalization and trans-barriers are provided in Table 1 . According to Kumari et al ${ }^{5}$ NP internalization occurs mainly through intracellular, paracellular, and transcellular pathways. However, endocytosis pathways are poorly understood regardless of their clinical significance and continued research. ${ }^{3}$ Continued research in this paradigm, coupled 


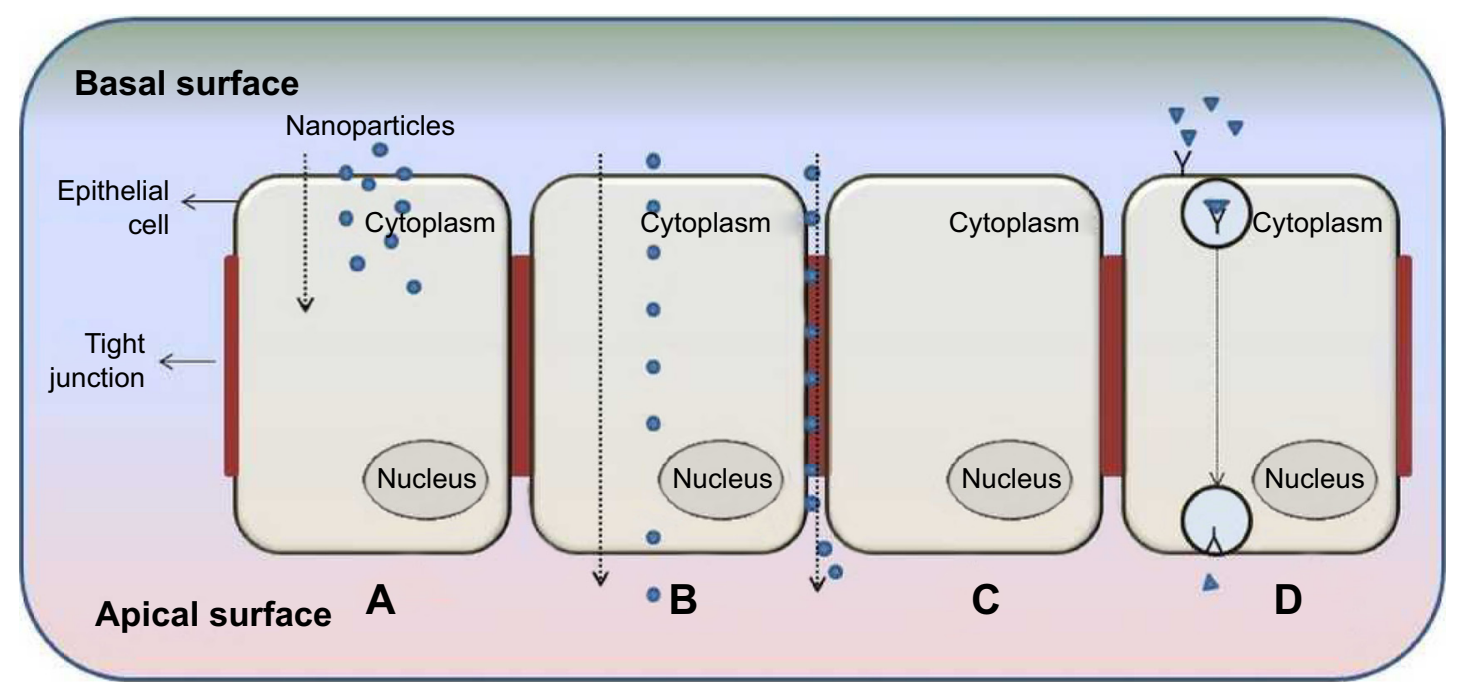

Figure I The transport mechanisms of a typical biological barrier.

Notes: (A) Cellular internalization of nanoparticle into cell via endocytosis; (B) transcellular transport of nanoparticles through cell; (C) paracellular transport of nanoparticle between cells through the tight junction; and (D) receptor-mediated transcytosis.

with nanoparticulate internalization and characterization, will provide immense insight into an ideal pharmaceutical formulation design.

Current studies on nanomedicine are encouraged in order to structure a framework that enables efficient, safer drug delivery and to eliminate many of the disadvantages posed by conventionally delivered drugs. Studies to specifically determine the effect of NP internalization are limited yet necessary in order to enhance biomedical technology and inform toxicity studies. Elucidating the parameters of NPs that enable them to target cells in response to disease-specific signals could significantly improve the therapeutic care of complex diseases. The current review therefore discusses NP properties and characteristics such as size, shape, charge, hydrophobicity, and ligand attachments that influence their uptake into target cells and through biological barriers. Intracellular pathways and current mechanisms employed to augment NP uptake and biological barrier transport were also discussed in detail.

\section{Transport mechanisms of nanocarriers} Intracellular endocytic delivery pathways

Various receptor-mediated pathways exist for cellular internalization of biological substances such as hormones and enzymes that require internalization to exert an effect at a cellular level (Figure 2). By adopting these mechanisms, drugs and NPs can be delivered to the necessary cell type. Cellular uptake mechanisms need to be understood in order to enhance internalization and identify NP characteristics that promote specific mechanisms. ${ }^{1}$ The mechanisms of different endocytic pathways as illustrated in Figure 1A are thoroughly described in the subsequent discussions.

\section{Pinocytosis}

Included in the pinocytosis classification are clathrin- and caveolae-mediated endocytosis and macropinocytosis. Clathrin-mediated endocytosis involves clathrin-coated vesicle formation in the presence of adaptor and accessory proteins.

Table I Key terms

\begin{tabular}{ll}
\hline Term & Definition \\
\hline $\begin{array}{l}\text { Cellular internalization } \\
\text { Endocytosis }\end{array}$ & $\begin{array}{l}\text { Process by which biological and foreign matter is taken up by cells. } \\
\text { Energy or enzyme-dependent mechanism of cellular internalization. } \\
\text { Trans-barrier }\end{array}$ \\
$\begin{array}{l}\text { Refers to transport of nano- and micro-substances through cells from extracellular fluid through the apical and } \\
\text { basolateral membrane. } \\
\text { Biological phenomenon whereby opsonin molecules adsorb onto the surface of foreign particles to enhance RES } \\
\text { recognition and phagocytosis. }\end{array}$ \\
PRINT particles & Particles fabricated using a lithographic technique of PRINT to produce monodisperse, shape-controlled particles.
\end{tabular}

Abbreviations: PRINT, particle replication in non-wetting templates; RES, reticuloendothelial system. 


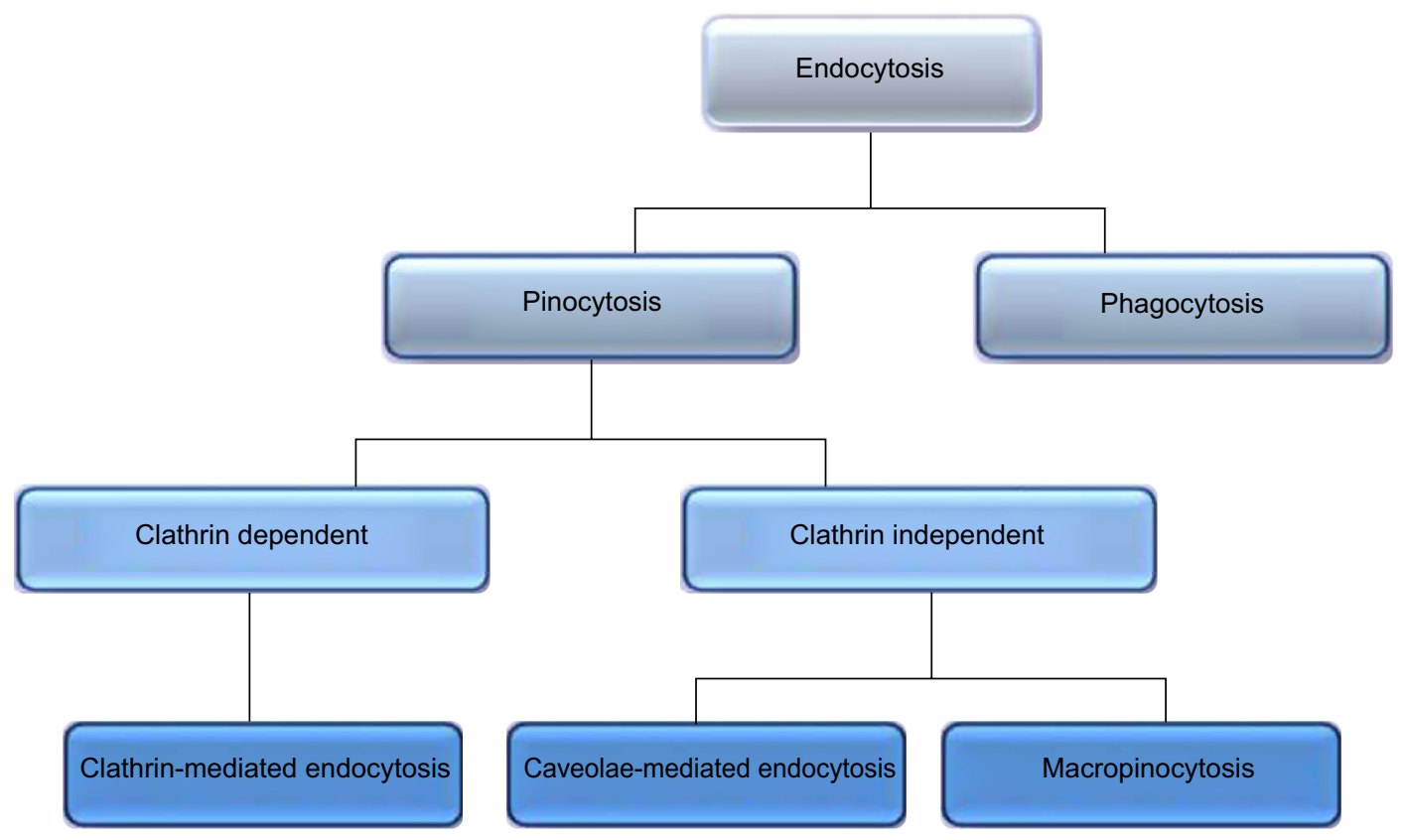

Figure 2 Mechanisms of endocytosis subdivided into categories of cell uptake.

Endocytic event cascade is activated by the signaling of the NP on the cell surface, ${ }^{6}$ which aligns surface proteins to prompt clathrin recruitment from the cytosol to begin clathrin-coating on the inner membrane of the cell. An adaptor protein, Epsin, is involved in the initial stages of membrane curvature and pit formation and accessory proteins such as dynamin (GTPase) affect vesicle formation from shallow to deep invagination by inducing deformation of the membrane. ${ }^{7}$ With the aid of dynamin, a clathrin-coated vesicle with a size of 100-150 nm is formed due to polymerization of the coat complex and the NP-containing clathrin-coated vesicle then internally detaches from the donor membrane. ${ }^{6}$ Once within the cell, clathrin and adaptor proteins uncoat to allow fusing of the vesicle within the cell to release the endocytosed NPs (Figure 3).

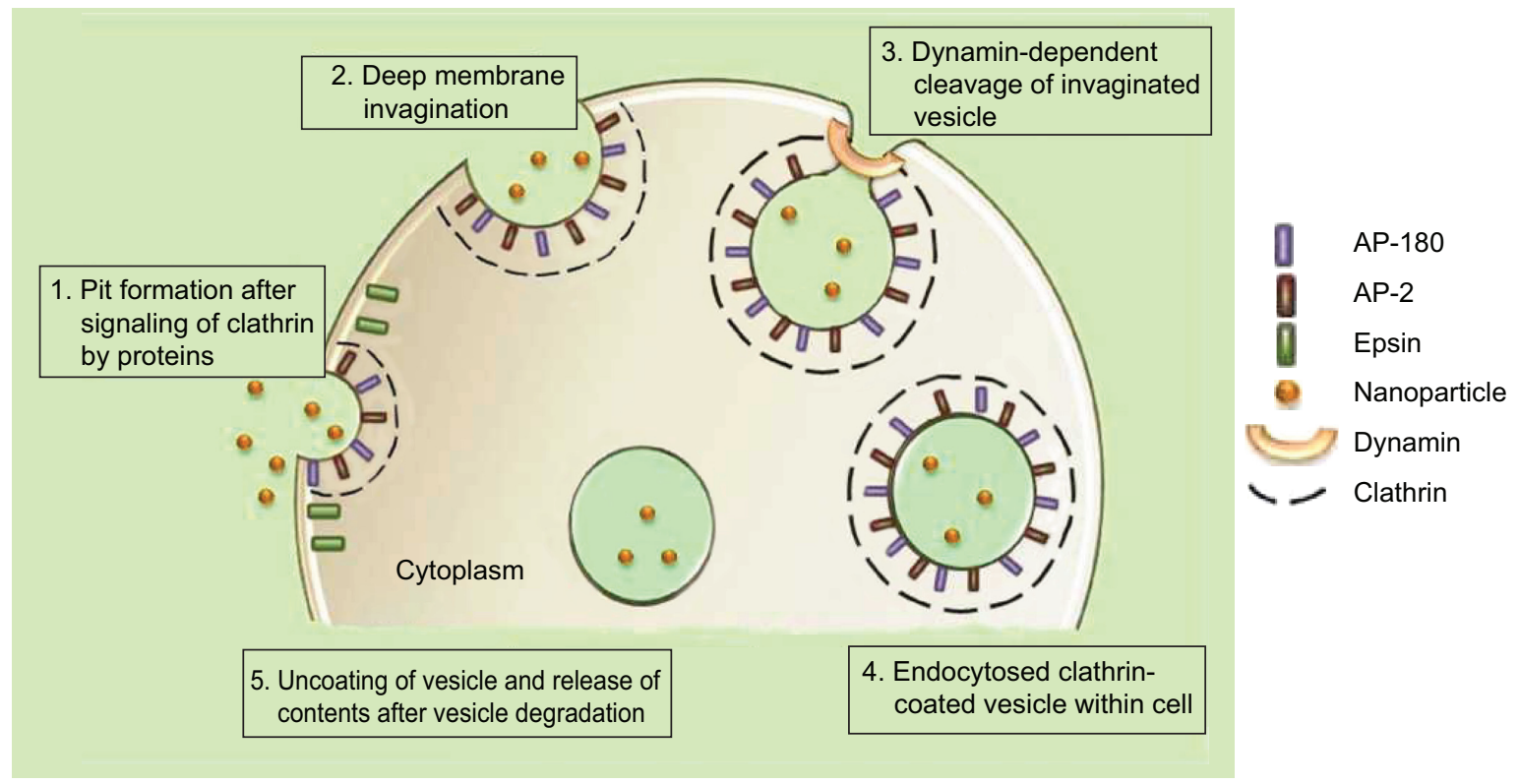

Figure 3 Mechanism of clathrin-mediated endocytosis of nanoparticles. 
Caveolae-mediated endocytosis is a pathway dependent on membrane cholesterol, dynamin, and cell receptor mediation. ${ }^{8}$ Caveolae are formed by a cluster of caveolin proteins (caveolin-1, -2, -3) that bind directly to membrane cholesterol, ${ }^{9}$ as shown in Figure 4. Complex signaling is driven by the cell membrane-bound NPs to be endocytosed, which induces actin reorganization and dynamin recruitment from the cytosol ${ }^{10}$ to stimulate membrane invagination and further on, vesicle budding. The uncoated invagination initially assumes a flask shape with a body diameter of $60-80 \mathrm{~nm}$ and a neck diameter of $10-15 \mathrm{~nm} .{ }^{11}$ Similar to clathrinmediated endocytosis, dynamin regulates vesicle budding of the caveolae to internalize cell membrane segments that contain the cargo and the caveolae membrane fuses into the acceptor compartment to release its contents.

\section{Macropinocytosis}

Macropinocytosis is a clathrin-, caveolin-, and dynaminindependent process that involves uptake of a larger volume of the membrane, also allowing for larger sized particles of sizes $>1 \mu \mathrm{m}$ to be internalized. ${ }^{12}$ The pathway proceeds by forming protrusions due to actin polymerization from the cell membrane, which then encapsulates the substance to be internalized and once again fuses back with the cell membrane. ${ }^{9}$ The process is initiated by activation of tyrosine kinases that signal a cascade of changes in the actin cytoskeleton and the formation of membrane protrusions. The random macropinocytic extensions enclose the material in the extracellular environment for cellular uptake (Figure 4) and collapse to fuse with the cell membrane, generating an internalized macrosome vesicle of an average of $\sim 10 \mu \mathrm{m} .{ }^{12,13}$ The uncoated membrane of the macrosome either acidifies and shrinks or fuses with the lysosomal compartment, consequently releasing the NPs into the intracellular compartment. ${ }^{14}$

\section{Phagocytosis}

Similar to macropinocytosis, phagocytosis is also a clathrin-, caveolin-, and dynamin-independent process and is proficient in internalizing larger particles such as drug nanocarriers and pathogens. ${ }^{14}$ It involves sequential instigation of receptors as a result of cell surface recognition of cargo, leading to internalizations by encircling it into triggered cup-shaped cell membrane deformations, forming a phagosome. ${ }^{9}$ The pathway begins with opsonization of the NPs, which then attach to the cell surface via Fc receptors and complement receptors, ${ }^{15}$ marking the beginning of actin polymerization and rearrangement and membrane extension to form surface extensions that encapsulate the opsonized NPs for internalization (Figure 4)..$^{14,16}$ A reduction and contraction of actin at the base of the cup allows for closure of the phagosome and the entire actinlined phagosome is then internalized with its contents. ${ }^{15}$ In a macropinocytotic manner, the vesicle undergoes degradation after transporting the opsonized particle into the cell.

\section{Transcellular delivery pathway}

As described by clathrin-dependent and clathrin-independent internalization, postuptake, the vesicle undergoes degradation. However, through other pathways, the vesicle can be transported to the other end of the cell surface, where its contents can be expelled into the extracellular environment as shown in Figure 1B. ${ }^{17}$ This pathway allows for lipophilic NPs and molecules to move efficiently through the transcellular route

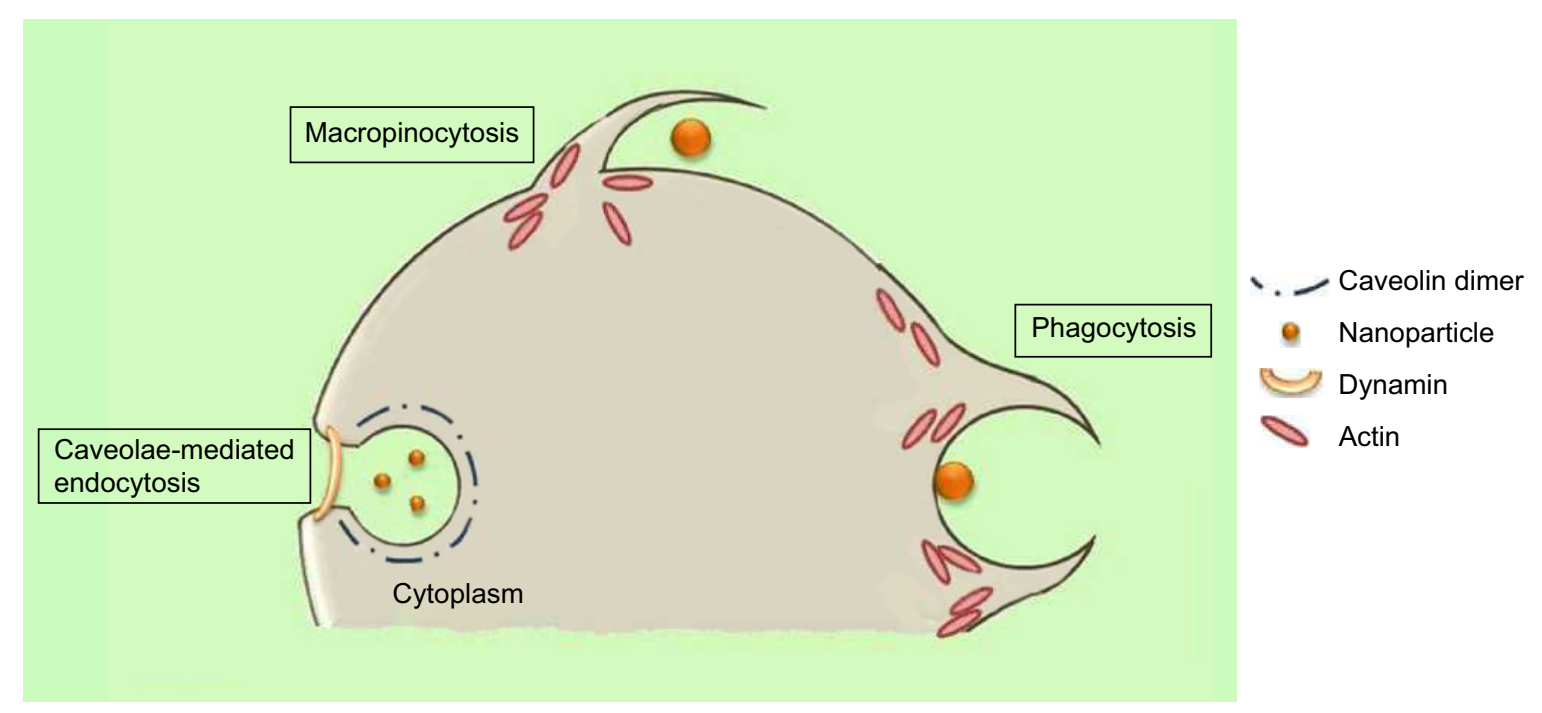

Figure 4 The mechanisms of caveolin-mediated endocytosis, macropinocytosis, and phagocytosis. 
by partitioning into and out of lipid bilayers via vesicular carriers due to its lipidic nature. ${ }^{18}$ The cargo to be transported binds to cell membrane receptors to form a complex. Membrane invagination is then initiated and the deep pit is internalized as a vesicle containing NPs. ${ }^{19,20}$ Following internalization, the endocytosed vesicle is sorted into a transcytotic vesicle to prevent typical endosome degradation. The transcytotic vesicle is then transported to the other end of the cell, where the vesicle membrane fuses with the cell membrane and the content of the vesicle is secreted externally. ${ }^{19,21}$

\section{Paracellular delivery pathway}

Paracellular delivery of drugs is a passive process that occurs between adjacent cells via tight junctions (TJs) through the intercellular space and not through the cell as described by transcellular delivery (Figure 1C). ${ }^{22}$ This route is specific for hydrophilic NPs and molecules, since hydrophilic molecules cannot cross biological membranes and as aqueous pathways that normally absorb nutrients, vitamins, or cofactors. ${ }^{18}$ Hydrophilic molecules are unable to cross biological membranes in the manner of lipophilic molecules due to the lipid properties of the cell bilayer membrane; therefore, targeting the paracellular pathway can significantly affect their transepithelial transport. Transit through this route is regulated by TJs that have heterogeneous pores with a variety of diameters of up to $15 \AA ;^{22}$ the overall charge of the TJ is negative and is therefore more responsive to positively charged NPs for paracellular permeation. ${ }^{23}$

\section{Parameters and characteristics of nanostructures governing cellular internalization}

The need for understanding the fundamental physicochemical characteristics of NPs and their pivotal role in cellular uptake is essential when designing smart nanosystems (Graphical Abstract). Ascertaining NP functionality provides basic and necessary information to influence the rational design of optimal nanocarriers by selectively delivering drug to targeted tissue to increase the rate of cellular uptake and effectively reduce drug-induced side effects. ${ }^{24-26}$ Other determining factors relating to cellular uptake are: 1) variation in the uptake pathways, ${ }^{27}$ 2) cell specificity, ${ }^{28} 3$ ) NP interaction with cell surface receptors, ${ }^{25}$ and 4) NP interaction with plasma proteins leading to NP-protein complex formation. ${ }^{29}$

\section{Particle size}

An important consideration regarding particle size is the $4 \mu \mathrm{m}$ diameter of the smallest blood vessels, as a micrometer-sized particle may cause an embolism. Acknowledging size should therefore not be limited to its internalization ability but also for its physical effects once inside the body. ${ }^{30,31}$ Cells within the human body vary from $1-100 \mu \mathrm{m}$, and therefore, have a low probability of internalizing particles of $\sim 100 \mu \mathrm{m}$. This particle size range for intracellular delivery is limited to the cells with a large enough capacity to host the particle. In addition to the higher rates of endocytosis of smaller sized NPs $(<100 \mathrm{~nm}),{ }^{12,32,33}$ experimental data also promote higher bioavailability of the endocytosed drug carrier at $100-1,000 \mathrm{~nm} \cdot{ }^{34,35}$ Various studies revealed that within a 1-100nm range, $50 \mathrm{~nm}$ NPs show maximum cellularuptake, with 14-20 nm NPs having a higher endocytotic rate than the $100 \mathrm{~nm}$ NPs. ${ }^{36-38}$ No significant difference in cellular uptake has been shown by NPs between $25-130 \mathrm{~nm},{ }^{39}$ while some reports postulate that NPs have higher internalization between $50-100 \mathrm{~nm} . .^{40}$ On the contrary, from a cellular uptake research experiment using thio-organosilica NPs of 50-500 nm, Awaad et $\mathrm{al}^{38}$ concluded that $95-200 \mathrm{~nm}$ is the ideal size for increased cellular uptake.

In an in vitro study undertaken by Nicolete et $\mathrm{al}^{41}$ after 4 hours of being culture incubated, $6.5 \pm 3.9 \mu \mathrm{m}$ poly(lacticco-glycolic acid) (PLGA) microparticles were still attached to the cell surface and required more time for endocytosis to occur. Simultaneously, PLGA NPs of size $389 \mathrm{~nm}$ (polydispersity index $=0.2$ ) had already, within the same time period, been encapsulated in vesicles and endocytosed into the intracellular compartment (Figure 5). These results were consistent with the study conducted by Loh et $\mathrm{al}^{42}$ which demonstrated poor internalization capability of chitosan particles that were $>1 \mu \mathrm{m}$, much unlike the extensive uptake of NPs of sizes 110-390 nm. Interestingly, Sahay et $\mathrm{al}^{12}$ stated that microparticles also enter cells but not as rapidly as NPs and concluded that poly(ethylene glycol) (PEG) particles $<5 \mu \mathrm{m}$ can gain entry into cells via pinocytosis. Likewise, considering the possibility of the aggregation of NPs, the size of an aggregated nanocluster is larger than a single NP and will affect the internalization rate accordingly. In vitro, the stability of the NPs should be controlled to promote a consistent nanosystem.

A research review compiled by Acosta $^{34}$ predominantly concluded that NPs with a size of $\leq 500 \mathrm{~nm}$ produce higher cellular uptake than NPs of a larger size. These results were also coherent with the enhanced penetration abilities of specialized nanocarrier systems that housed the NPs. The uptake of NPs with a size of $500 \mathrm{~nm}$ has a lower viability but may be promoted with the use of a constructive, complementary delivery system. Essentially, an assisting 


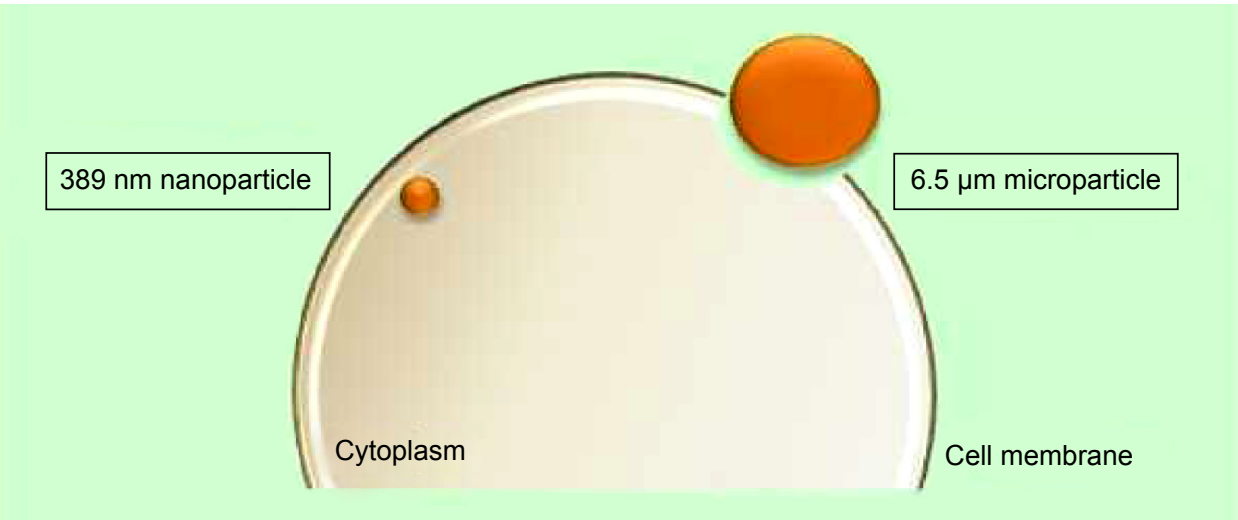

Figure 5 Representation of the internalization potential dependent on particle size.

Note: The larger surface area of the nanoparticle allows for increased surface contact with the cell membrane for higher internalization rates as described in the investigation of Nicolete et al. ${ }^{41}$

delivery system would have lipophilic properties or a suitable surface charge for enhanced internalization.

Despite several studies promoting the use of smaller NPs $(<100 \mathrm{~nm})$, disparities exist in other studies providing evidence that particle size affects internalization as significantly as its complementary system. The variation in internalization profiles and NP size demonstrates that the influence of NP size is also dependent on the type of cells and the chemical composition of the nanomaterial. ${ }^{12,42}$

\section{Surface charge}

Charge parameters are vital in the characterization of NPs, as they determine aggregation in the blood or interaction with oppositely- and like-charged cell membrane surfaces. A plethora of studies concluded that cationic and neutral particles show the highest transport efficiency compared to negatively charged particles due to the charge attraction between the positive NPs and negative cell membrane surface, thereby increasing the rate and extent of internalization. ${ }^{33,43-45}$ These electrostatic forces are long-range forces and can act across intervening aqueous space. ${ }^{46}$

\section{Cationic and neutral nanoparticles}

In the study by Jallouli et $\mathrm{al}^{47}$ the uptake of $60 \mathrm{~nm}$ neutral and cationic maltodextrin porous NPs with a phospholipid core was investigated in brain capillary endothelial cells. Neutral NPs were endocytosed in the caveolae-mediated pathway, while the cationic NPs were found to utilize the paracellular pathway due to the rich anionic sites found on the luminal surface of the endothelial cells. The cationic NPs had a stronger charge affinity to the collagen fibers on the surface of the endothelial cells, thus impeding drug delivery, while the neutral NP sample showed better transcytosis into the targeted cells.

\section{Cationic nanoparticles}

Karlsson et al ${ }^{48}$ showed that cationic particles had a 2.5 -fold higher uptake than neutral particles and a 25 -fold higher uptake than anionic particles, concluding that cationic particles are transported using the paracellular pathway to a greater degree than neutral or anionic particles. These results contradict the study by Lin et a ${ }^{49}$ who concluded from their experimental study that cationic and neutral gold-coated NPs were internalized via endocytosis while anionic NPs showed lesser permeability and were trafficked through the paracellular pathway.

\section{Anionic nanoparticles}

Contrary to the abovementioned research, many studies have shown the successful internalization of negatively charged NPs. An interesting study conducted by Harush-Frenkel et $\mathrm{al}^{43}$ concluded that both anionic and cationic PEG-DL-polylactide (PLA) NPs accumulated within MDCK and HeLa cells. The internalized anionic NPs underwent a degradative lysosomal process and were unable to undergo further transcytosis, rendering cationic NPs more suitable for cellular drug delivery. Likewise, negatively charged quantum dot NPs were, in fact, endocytosed through a caveolae-mediated pathway, while cationic quantum dot NPs used a clathrin-mediated pathway, internalizing HEK cells. ${ }^{50}$ Both charged quantum dots were internalized via endocytosis with no specific rationalization to endocytic preference. Despite the hypothesis of NPs with a negative charge having a slower uptake rate due to repulsive forces, 
research has shown that certain anionic NPs internalize more readily. From this discussion, it can be deduced that anionic NPs have the ability to undergo internalization via caveolae pathways, whereas cationic NPs commonly use the clathrin pathways. ${ }^{43,50}$ Highly charged negative NPs also favor good stability since the Coulombic repulsion forces arising from their surface charge can overcome the Van der Waals attractive forces between them and prevent aggregation. $^{51}$

\section{Particle shape}

Functional behavior and internalization of particles in drug delivery are strongly influenced by their shape..$^{52}$ Although few researchers have focused on shape, those who have, have made noteworthy contributions, but with contradicting results. ${ }^{53}$ In many of the following studies, NP shape was the key factor for enhanced internalization, proving its pivotal role in NP fabrication. Chithrani et $\mathrm{al}^{36}$ investigated the uptake of gold spherical and rod-shaped NPs. The $74 \mathrm{~nm}$ and $14 \mathrm{~nm}$ spherical NPs had a higher uptake when compared to $74 \times 14 \mathrm{~nm}$ rod-shaped NPs by $500 \%$ and $375 \%$, respectively, which support their claim that spherical particles have a higher internalization probability. The speculation is that the difference in curvature between the two shapes determines cell surface binding. When the longitudinal axis of the rod-shaped NP is in contact with the cell surface, it has a larger area of contact with the cell membrane receptors compared to spherical NPs, and therefore blocks the remaining available membrane receptors, reducing the number of NPs being internalized. Han et $\mathrm{al}^{54}$ have reported similar results that prove that spherical particles internalize substantially quicker than asymmetrically shaped particles. Champion and Mitragotri ${ }^{55}$ reported on the correlation between contact angle and particle internalization, concluding that rod-shaped NPs have a higher likelihood of internalization when their major axis is perpendicular to the cell membrane. The long axis of the rod aligned perpendicular to the cell will increase the internalization rate and the rate will decrease as $\varnothing$ increases (Figure 6). This theory is based on the orientation of the NP to the cell membrane and could further dictate the synthesis of NP shapes with several short aspects to enhance internalization.

Another theory was reported by Gratton et $\mathrm{al}^{57}$ through a study using various shaped PEG-based PRINT (particle replication in non-wetting templates) particles. Among different shapes investigated, nano-cylinders were internalized to a considerably larger extent than micro-cylinders and nanocubes. The higher cell uptake was speculated to be due to the larger surface area, allowing for more multivalent ionic interactions with the cell membrane, which then undergo endocytosis and phagocytosis. ${ }^{57}$ This theory was supported by Sadeghi et $\mathrm{a}^{58}$ who based the highest antibacterial activity of silver nano-plate NPs compared to nano-spheres and nano-rods on the larger surface area that binds with the bacterial cells, as well as by Hao et $\mathrm{al}^{53}$ who proved that mesoporous silica longrod NPs had higher internalization and retention than spheres and short rods. In addition, various nano-shaped particles have also been shown to have diverse accumulation capabilities in different organ systems. Decuzzi et al ${ }^{59}$ identified the shape
A

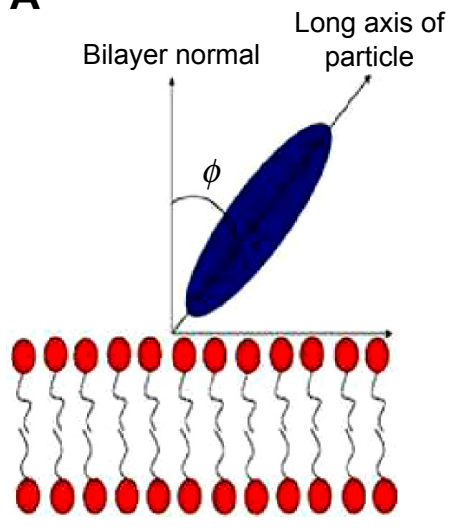

B

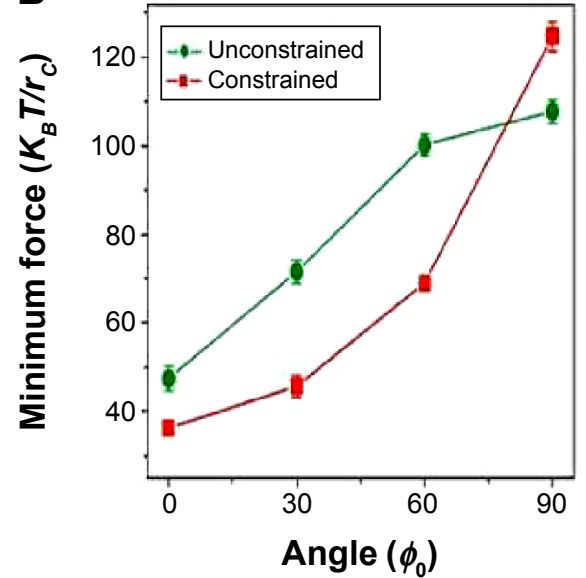

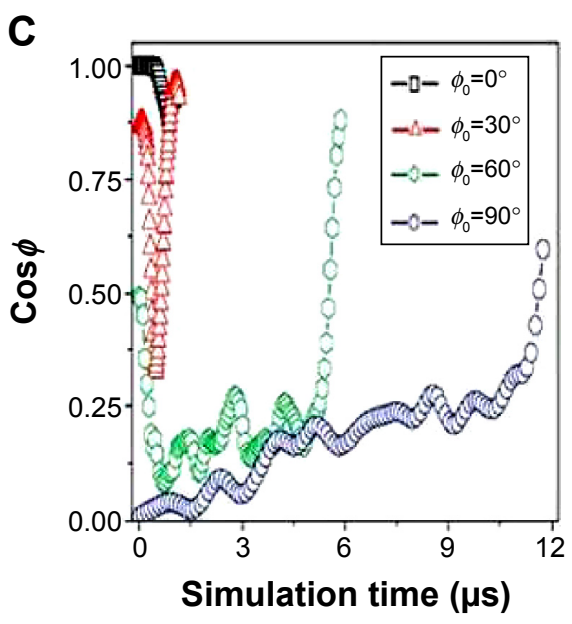

Figure 6 Particle internalization based on orientation to the membrane.

Notes: (A) Schematic showing the angle between the long axis of the particle and the bilayer normal; (B) minimum driving forces required to guide the ellipsoid with different initial orientations of the long axis through the lipid bilayer; (C) time evolution of particle orientations during the ellipsoid penetration processes with different initial orientations. Reprinted by permission from Macmillan Publishers Ltd: Nature Nanotechnology. Yang K, Ma YQ. Computer simulation of the translocation of nanoparticles with different shapes across a lipid bilayer. Nat Nanotechnol. 20I0;5(8):579-583. Copyright (C) 20I0.56 
effect of silicon NPs and their accumulation in specific tissues, which they evaluated from their biodistribution data, that in the lung discoidal-shaped NPs tended to internalize more than spherical, cylindrical, and quasi-hemispherical NPs. In the liver, cylindrical NPs accumulated more than the other three shapes, discoidal-shaped NPs accumulated most in the heart, and discoidal and quasi-hemispherical NPs had the highest internalization in the spleen tissue. These results were further corroborated by Park et al, ${ }^{60}$ who demonstrated that nano-worms had a higher tumor uptake in a fibrosarcoma and breast cancer cell line compared with spherical NPs, and Devarajan et $\mathrm{l}^{61}$ who showed preferential accumulation of irregular spherical NPs in the spleen, while regular spherical NPs accumulated in the liver.

Contrary to the abovementioned observations that promote nonspherical NPs as possessing higher internalization, we cannot deduce that spherical NPs are less conducive for internalization, as several studies attest to their dynamic characteristics and unmatched high surface area to volume ratio. In fact, if considering therapeutic potential of NPs, then spheres should be superior to nonspherical NPs due to their excellent drug-loading capacity. Many researchers claim hypothetical theories on the internalization kinetics based on NP shape; however, we cannot deny that all of these NPs investigated do not have constant additional NP parameters, and these would also impact on the rate of cellular uptake.

\section{Surface properties}

The surface properties of NPs are as fundamental as the other key characteristics that dictate internalization. For targeted drug delivery, high circulation time of NPs in the body is required for the NPs to recognize their specific site of interest. Opsonins adsorbing to the surface of hydrophobic NPs decrease circulation time by initiating the immune response cascade which allows phagocytosis of the NPs following recognition as foreign objects. If the drug is unnecessarily taken up by the reticuloendothelial system, drug bioavailability is reduced and undesirable effects are exerted on the immune system and pose the threat of toxicity within the host. ${ }^{62,63} \mathrm{NP}$ hydrophobicity may instigate redundant interaction with plasma proteins, phagocytic internalization, immune cell stimulation and particle clearance. ${ }^{64}$ Minimizing the recognition of NPs by the reticuloendothelial system and subsequent immune system will enhance the probability of uptake by the target cells. Hence, recent research is focused on modifying conventional hydrophobic NP surfaces with a hydrophilic protective layer. This layer creates a cloud of chains at the NP surface to cause steric repulsive forces against plasma proteins and increase the blood circulation half-life of targeted nanocarriers as shown in Figure 7. ${ }^{24,65-67}$ Hydrophilic-coated NPs can be fabricated by making use of polymer types such as PEG, PEG-based copolymers and poly-vinyl pyyrolidone (PVP). ${ }^{65,68}$

Physicochemical surface parameters can affect cellular uptake as reported in the recent study conducted by Loh et al. ${ }^{42}$ The study ascertained the theory of concentration-dependent chitosan molecules increasing NP transport through membranes by disrupting the integrity of intercellular TJs involved in paracellular transport. ${ }^{69}$ Chitosan redistributes cytoskeleton proteins such as actin and tubulin found in the apical membrane resulting in the opening of TJs. ${ }^{70}$ Using chitosan-coating as a surface modification for NPs could optimize paracellular transport and deliver a higher amount of drug-loaded nanocarriers to the targeted site.

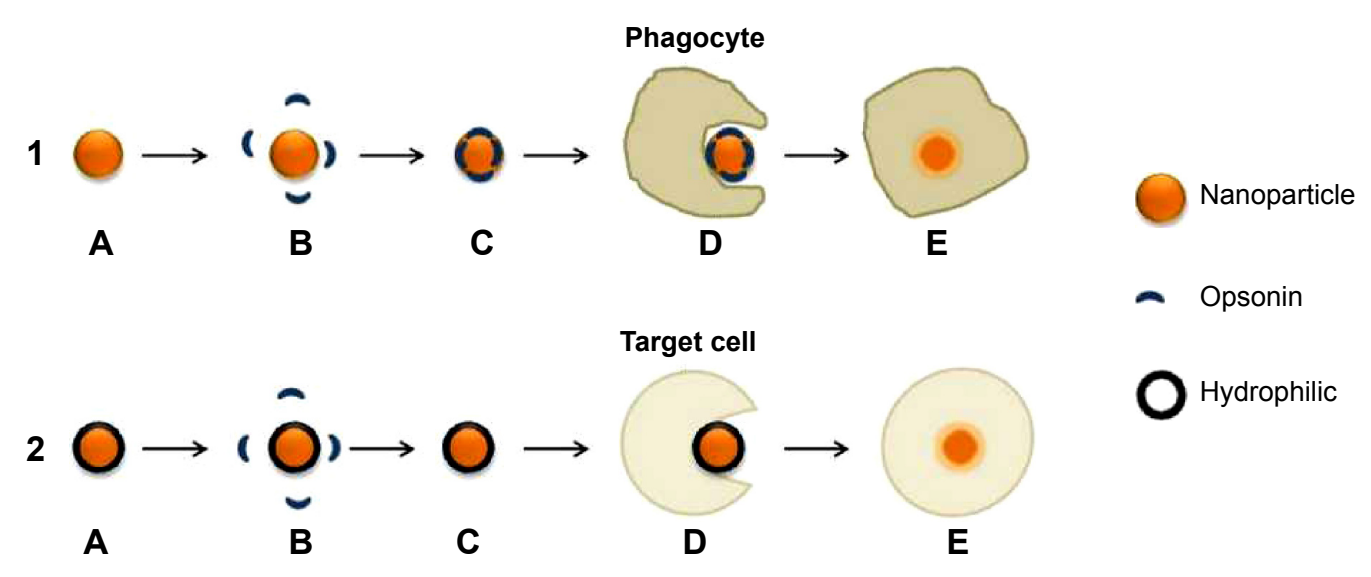

Figure 7 (I) Pathway of uncoated hydrophobic nanoparticle; (2) pathway of coated hydrophilic nanoparticle.

Notes: (I) (A) Nanoparticle in blood circulation; (B) opsonins recognize nanoparticle as a foreign body due to the hydrophobic surface; (C) opsonization of nanoparticle; (D) and (E) phagocytosis by phagocyte and elimination of nanoparticle. (2) (A) Hydrophilic polymer-coated nanoparticle in blood circulation; (B) steric hindrance maintains repulsive forces between opsonins and nanoparticle; (C) nanoparticle continues to circulate until target site reached; (D) and (E) endocytosis by target cell. 
An interesting recent advance in research shows the coating of a polymeric NP core with red blood cell (RBC) membranes. Luk et $\mathrm{al}^{71}$ synthesized a cloaked NP utilizing the $\mathrm{RBC}$ membranes to evade the immune response cascade resulting in a prolonged in vivo circulation time. This bioinspired nano-system enhances the probability of NP uptake and if coupled with other NP factors to promote increased cellular uptake may prove to be yet another breakthrough drug delivery system. Therefore, modulating surface characteristics can control internalization rate, extent and even transport pathways. However, in order to achieve the desired outcome, the selection as well as manipulation of appropriate biomaterials for coating is imperative.

\section{Proteins and ligand attachments}

Cell-penetrating proteins or peptides (CPPs) can increase cellular uptake of surface-modified drug-loaded NPs by employing direct cell penetration or receptor-mediated endocytic pathways and localizing NPs at the required site. ${ }^{72,73} \mathrm{CPPs}$ are small amphipathic or cationic polypeptides (10-30 amino acids long) inclusive of trans-activating (TAT) peptide, penetratin, transportan, toxins, poly-arginine, and rabies virus glycoprotein (RVG). ${ }^{74,75}$ A possible mechanism of the TAT protein is that it binds to cell surface heparin sulfate proteoglycans and is then internalized through receptor-mediated uptake (Figure 8).

Bareford and Swaan ${ }^{76}$ reviewed cell adhesion molecules (CAMs), which form part of the subfamily of immunoglobulins. CAMs bind to cell adhesion receptors (CARs) on cell surfaces and stimulate clathrin-mediated uptake. Peptides such as Arg-Gly-Asp (RGD) bind to CARs and have been used extensively to promote the uptake of drug-loaded NPs. Furthermore, cationic proteins have a higher affinity to negatively charged cell membranes, which further promotes cellular internalization. ${ }^{33,76}$ Ligands for enhanced cellular uptake include folic acid, albumin, and cholesterol, which are internalized using caveolae-mediated uptake, and are common, attractive methods to stimulate spontaneous uptake through receptors ${ }^{76}$ In contrast, Pujals and Giralt ${ }^{77}$ reviewed the highly improved internalization efficiency of fatty acids or silaproline, which is a hydrophobic derivative of proline-rich, amphipathic CPPs. Targeting tissue-specific receptors and molecules by using antibodies has also proven to be useful for enabling internalization of drug-carriers intended for site-specific delivery. This strategy requires the conjugation of receptor-specific ligands and proteins to the NP coat. The potential for binding to the target tissue is dependent on the abundance of the ligand and its specificity and affinity for binding to the target cell membrane. ${ }^{3}$

By targeting the monoclonal antibody to the protein aminopeptidase $\mathrm{P}$ (APP) in the lung, in vivo transport across the endothelial barrier to lung tissue occurs within seconds. ${ }^{78}$ NPs that are surface modified with cyclic RGD peptides preferably bind to $\alpha_{\mathrm{v}} \beta_{3}$ integrin receptors. In comparison to unmodified NPs, these peptide functionalized NPs internalize more readily into HeLa cells. ${ }^{79}$ This concept can be applied to tumor cells that contain specific membrane antigens where the surface of the drug carrier is modified with the corresponding antibody for increased binding and uptake. This is experimentally shown by targeting prostatespecific membrane antigen, ${ }^{80}$ transferrin-conjugated NPs that demonstrated higher cellular uptake in a prostate cancer cell line ${ }^{81}$ and monoclonal antibody-conjugated PLGA NPs for increased tumor cell uptake. ${ }^{82}$ In contrast, quantitative and biodistributive data from the study conducted by Huang et a ${ }^{83}$ showed that three different ligands (single-chain variable fragment, amino terminal fragment, and cyclic RGD peptide) only marginally improved gold NP accumulation in tumor tissue in comparison with nontargeted controls. ${ }^{83}$ Similarly, Temsamani and Vidal ${ }^{84}$ reviewed the construct of phosphopeptides linked with penetratin as having inhibitory effects on ligand-dependent transduction pathways in various cell lines,

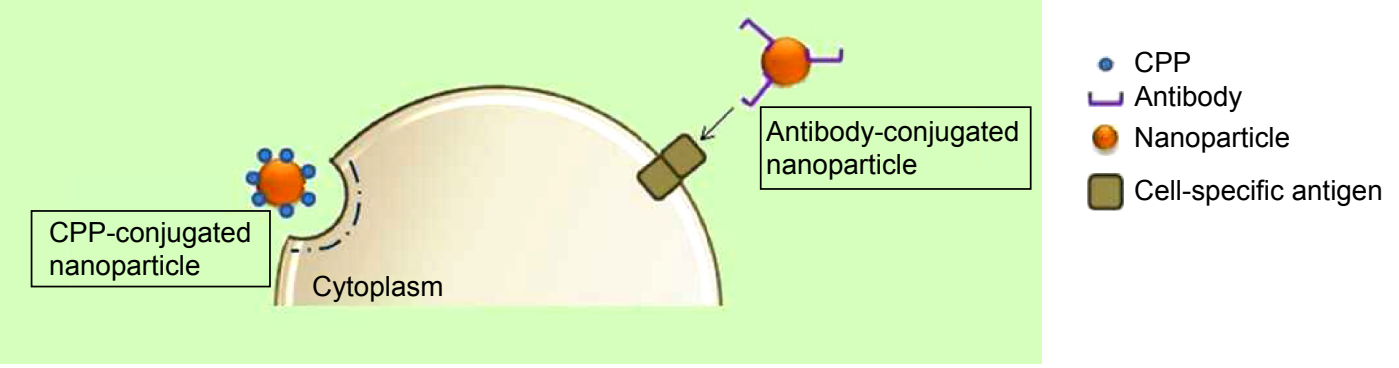

Figure 8 Stimulating endocytosis through CPP and antibody conjugation of nanoparticles. Abbreviation: CPP, cell-penetrating protein or peptide. 
even though individually, these CPPs promote internalization. The use of serum protein attachments on gold NPs was shown to improve their uptake half-life, rate, and extent. ${ }^{36} \alpha$ - and $\beta$-globulin proteins are known to be internalized by cells and increasing the diversity of protein attachments may allow entrance into cells via the receptor-mediated pathways. However, another study reported that serum protein attachments inhibited the uptake of polyvalent gold NPs, and that instead, uptake is dependent on scavenger receptors. ${ }^{85}$

Taking note of the use of a cationic mixed monolayer of CPPs and PEG, Liu et $\mathrm{al}^{86}$ proved its efficiency on internalization rates of gold NPs by combining these factors. The multifunctional NPs show superior uptake when compared to NPs synthesized exclusive of the addition of CPP or having an anionic surface charge. Thus, drug delivery scientists have capitalized on the knowledge of receptors and ligands as targeting moieties for specific cellular organelle targeting. ${ }^{76,87}$ This principle is not only applied to general cells but can also be adopted for specific targeting to tumors for increasing the bioavailability of drugs to the target site.

\section{Current advances in trans-barrier internalization}

It has been discussed how the inherent physical and chemical properties of NPs such as size, shape, surface charge, solubility, surface characteristics, and ligand complexes can dictate the degree of biocompatibility and internalization kinetics for NPs, as well as the selectivity of these factors for specific cell types. The additional key parameter for consideration in the uptake of NPs is the environment the nanosystem comes into contact with ${ }^{29}$ and the manner in which we can engineer these parameters to trigger different biological responses. ${ }^{69}$ As discussed by Brannon-Peppas and Blanchette, ${ }^{88}$ the size of NPs for crossing biological barriers is dependent on the tissue, target site, and circulation. Likewise, all other NP characteristics need to be fabricated in consideration of inherent target tissue requirements for cellular internalization. Barrier capacity and trans-compartment transport of particles vary considerably between different tissue types. ${ }^{89}$ Limited transport across the epithelia is one of the prime obstacles for therapeutic agents and nanomedicines reaching the adequate biological compartment, ${ }^{1}$ as barrier systems are unable to evaluate and differentiate drug delivery systems for translocation from foreign particles, and therefore restrict the entry of the drug carriers, rendering the system invaluable and reducing its efficacy.

The delivery of therapeutic agents requires successful negotiation of these barriers in order to attain a sufficient therapeutic index..$^{90}$ To transverse these barriers using smart nanosystems, the development of efficient nanomedicines requires a thorough understanding of the characteristics of the body's systems, biological barriers, and mechanisms to evade foreign particle interactions in the body. Once the characteristics of the biological systems are defined, we can identify NP parameters that enhance transmembrane transport or cellular uptake (Table 2). From the data reported in Table 2, it is evident that various nanosystems contributing different parameters and characteristics are able to transverse biological barriers dictated by the barrier's set of limitations and specific NP criteria for internalization.

\section{Conclusion}

The scope for further research into this concept has immense potential to progress medical care by decreasing side effect profiles due to specific and targeted drug release, improving bioavailability, and bypassing first-pass metabolism. The use of sophisticated nanomedicines as effective vectors of drugs exerts beneficial effects at the molecular level, providing targeted drug delivery. The forefront of nanomedicine research comprises diagnosis, treatment, monitoring, and management of biological conditions. Independently, nanotechnology has surfaced as one of the most successful drug delivery concepts to date, and it is obvious that applications for biomedical nanotechnology are broad. This review encompasses possible techniques of NP manipulation to further improve intracellular delivery of drugs. The benefits of enhanced cellular internalization have been extensively motivated and the scope for further research in this domain is constant. Therapeutic advantages can be demonstrated by increasing NP cellular uptake, targeting site-specific organ systems by increasing selectivity, and even altering the drug release kinetics of the nanosystem and biodistribution. Taking this concept into consideration also allows for a single NP of ideal characteristics to encapsulate several drugs for delivery to enhance efficacy and possibly reduce resistance. Furthermore, the diversity of NP parameters with regards to targeting ligands can be studied thoroughly to assist with the internalization of macromolecule drugs that primarily have difficulty penetrating the cell membrane.

Apart from cellular internalization, focus has been placed on nuclear targeting via a nuclear localization signal (NLS). ${ }^{14-145}$ At a complex level, drug delivery targeting intracellular organelles postcellular internalization may prove to be a research area of high interest. Included in this paradigm is the possibility of the multistage drug targeting of NPs from bypassing the cellular membrane 
Table 2 Overview of biological barriers and nanoparticle advances to overcome physiological limitations

\begin{tabular}{|c|c|c|c|c|}
\hline $\begin{array}{l}\text { Organ } \\
\text { system }\end{array}$ & $\begin{array}{l}\text { Barriers to } \\
\text { internalization }\end{array}$ & $\begin{array}{l}\text { Physicochemical nanoparticle } \\
\text { modification }\end{array}$ & $\begin{array}{l}\text { (Trans)-epithelial } \\
\text { transport mechanisms }\end{array}$ & Reference \\
\hline \multirow[t]{5}{*}{ Skin } & $\begin{array}{l}\text { Insoluble corneocytes and tight } \\
\text { junctions in viable epidermis }\end{array}$ & $\begin{array}{l}\text { - Chemical enhancers } \\
\text { (oleic acid, ethanol, PEG) } \\
\text { to surface coat }\end{array}$ & $\begin{array}{l}\text { Pores, trans/intercellular, } \\
\text { follicular penetration }\end{array}$ & 91,92 \\
\hline & & $\begin{array}{l}\text { - } 215.2 \mathrm{~nm} \text { anionic quercetin-loaded } \\
\text { lipid NPs }\end{array}$ & Intercellular permeation & 93 \\
\hline & $\begin{array}{l}\text { Pilosebaceous }(10-70 \mathrm{~mm}) \text { and } \\
\text { sweat glands }(60-80 \mathrm{~mm})\end{array}$ & $\bullet<10 \mathrm{~nm}$ metal maghemite NPs & $\begin{array}{l}\text { Lipidic matrix, follicular } \\
\text { penetration }\end{array}$ & 94 \\
\hline & Intercellular lipidic matrix & $\begin{array}{l}\text { - Hydrophilic } 40 \text { nm irregular, spherical } \\
\text { PEG-b-copolymer NPs }\end{array}$ & Follicular penetration & 94,95 \\
\hline & & $\begin{array}{l}\text { - } 18 \mathrm{~nm} \text { hydrophobic cationic/neutral } \\
18 \mathrm{~nm} \text { ellipsoid/spherical quantum dots }\end{array}$ & $\begin{array}{l}\text { Pores, follicular } \\
\text { penetration }\end{array}$ & 96 \\
\hline \multirow[t]{2}{*}{ Blood } & $\begin{array}{l}\text { Complement system, } \\
\text { phagocytosis }\end{array}$ & $\begin{array}{l}\text { - Heparin-complexed cerium oxide NPs } \\
\text { for monocyte drug delivery }\end{array}$ & & 97,98 \\
\hline & White blood cells & $\begin{array}{l}\text { - Cell membranes contain regions } \\
\text { of +ve and -ve charge, NPs of either } \\
\text { charge can be internalized }\end{array}$ & & 98 \\
\hline \multirow[t]{3}{*}{ Ocular } & Blood-aqueous barrier & $\begin{array}{l}\text { - I80 nm anionic sparfloxacin-loaded } \\
\text { PLGA NPs }\end{array}$ & $\begin{array}{l}\text { Nasolacrimal } \\
\text { drainage system }\end{array}$ & 99,100 \\
\hline & Blood-retinal barrier & $\begin{array}{l}-3.46 \mu \mathrm{m} \text { surfactant-complexed } \\
\text { multilamellar acetazolamide niosomes }\end{array}$ & & 100,101 \\
\hline & Precorneal tear film $(3-10 \mu \mathrm{m})$ & $\begin{array}{l}\text { - } 161 \text { nm PEG-coated poly- } \varepsilon \text {-caprolactone } \\
\text { nanocapsules }\end{array}$ & Transcytosis & 102 \\
\hline \multirow[t]{4}{*}{ Spinal cord } & $\mathrm{BSCB}$ & - 2-5 nm cerium oxide NPs & & 103,104 \\
\hline & Astrocytic foot processes & - Ideal properties for penetrating & & 103 \\
\hline & & BSCB/astrocytic foot processes & & \\
\hline & & $\begin{array}{l}\text { - NP size }(<50 \mathrm{~nm}) \text {, cationic, hydrophilic, } \\
\text { CPP-complexed }\end{array}$ & & $\begin{array}{l}12,36 \\
45,67,74\end{array}$ \\
\hline \multirow[t]{11}{*}{ Brain } & $\begin{array}{l}\text { BBB, blood-cerebrospinal } \\
\text { fluid barrier }\end{array}$ & $\begin{array}{l}\text { - Hydrophilic PEG-coated poly hexadecyl } \\
\text { cyanoacrylate }\end{array}$ & $\begin{array}{l}\text { Caveolae-mediated } \\
\text { endocytosis }\end{array}$ & 105,106 \\
\hline & & $\begin{array}{l}\text { - Chemical/biological/physical modulators } \\
\text { for opening BBB }\end{array}$ & Trans/paracellular & 107,108 \\
\hline & Enzymatic BBB & $\begin{array}{l}\text { - MAb 5C6, to CR3 receptor-a } \beta_{2-}^{-} \\
\text {integrin present on microglia }\end{array}$ & $\begin{array}{l}\text { Receptor-mediated } \\
\text { transcytosis }\end{array}$ & 109 \\
\hline & & $\begin{array}{l}\text { - RMP-7 (bradykinin analog)-coated } \\
50 \mathrm{~nm} \text { NPs }\end{array}$ & & 110 \\
\hline & & - Polyether-copolyester dendrimers & $\begin{array}{l}\text { Clathrin/caveolae- } \\
\text { mediated uptake }\end{array}$ & 111 \\
\hline & $\begin{array}{l}\text { High transendothelial electrical } \\
\text { resistance of } 1,500-2,000 \mathrm{~V} / \mathrm{cm}^{2}\end{array}$ & $\begin{array}{l}\text { - Cationization of antibodies to undergo } \\
\text { active transport }\end{array}$ & $\begin{array}{l}\text { Absorptive mediated } \\
\text { transcytosis }\end{array}$ & 109 \\
\hline & & $\begin{array}{l}\text { - Anionic, } 90 \mathrm{~nm} \text { transferrin (Tf)- } \\
\text { conjugated polymersomes }\end{array}$ & $\begin{array}{l}\text { Tf receptor-mediated } \\
\text { transcytosis }\end{array}$ & 112 \\
\hline & & - Anionic, $\leq 200 \mathrm{~nm}$ SLNs & & 113 \\
\hline & & $\begin{array}{l}\text { - Cationic, 190-210 nm nano-lipid } \\
\text { emulsion }\end{array}$ & $\begin{array}{l}\text { Caveolae-mediated } \\
\text { end/macropinocytosis }\end{array}$ & 114 \\
\hline & $\begin{array}{l}\text { Brain extracellular space of } \\
38-64 \mathrm{~nm}\end{array}$ & $\begin{array}{l}\text { - Anionic, I54 nm PLGA NPs via inner } \\
\text { ear administration }\end{array}$ & Pinocytosis & 115,116 \\
\hline & & $\begin{array}{l}\text { - } 80 \mathrm{~nm} \mathrm{TiO} \mathrm{TP}_{2} \mathrm{NPs} \text { administered through } \\
\text { intranasal instillation }\end{array}$ & Transcytosis & 117 \\
\hline \multirow[t]{4}{*}{ Liver } & $\begin{array}{l}\text { Tight junctions, } 5-10 \mu \mathrm{m} \\
\text { wide } \mathrm{BVs}\end{array}$ & $\begin{array}{l}\text { - Filo-shaped micelles with high } \\
\text { aspect ratios and cylindrical shape }\end{array}$ & $\begin{array}{l}\text { Clathrin/caveolae- } \\
\text { mediated endocytosis }\end{array}$ & $59,118,119$ \\
\hline & & - 20 nm carboxylated polystyrene & & 120 \\
\hline & & $\begin{array}{l}-47.2 \mathrm{~nm} \text { cationic chitosan NPs } \\
\text { of irregular shape modified with } \\
\text { glycyrrhizin complexation }\end{array}$ & $\begin{array}{l}\text { Receptor-mediated } \\
\text { endocytosis }\end{array}$ & $|2|$ \\
\hline & $\begin{array}{l}\text { Phagocytic properties } \\
\text { of juxtaposed Kupffer } \\
\text { cells }\end{array}$ & $\begin{array}{l}\text { - CPPs conjugated on }<90 \mathrm{~nm} \text { cationic } \\
\text { NPs to target AGP receptors on } \\
\text { hepatocytes for direct drug delivery }\end{array}$ & $\begin{array}{l}\text { Receptor-mediated } \\
\text { endocytosis }\end{array}$ & 122 \\
\hline
\end{tabular}


Table 2 (Continued)

\begin{tabular}{|c|c|c|c|c|}
\hline $\begin{array}{l}\text { Organ } \\
\text { system }\end{array}$ & $\begin{array}{l}\text { Barriers to } \\
\text { internalization }\end{array}$ & $\begin{array}{l}\text { Physicochemical nanoparticle } \\
\text { modification }\end{array}$ & $\begin{array}{l}\text { (Trans)-epithelial } \\
\text { transport mechanisms }\end{array}$ & Reference \\
\hline & & $\begin{array}{l}\text { - Saturating Kupffer cells with excess } \\
\text { of drug-loaded NPs }\end{array}$ & & 119 \\
\hline & & $\begin{array}{l}\text { - Particles of I-3 } \mu \mathrm{m} \text { evade ruffled surface } \\
\text { of Kupffer cells }\end{array}$ & & 123 \\
\hline & Protective mucin layer & - Neutral, hydrophobic NPs $<200 \mathrm{~nm}$ & & 124 \\
\hline Oral cavity & $\begin{array}{l}\text { Non-keratinized epithelia, } \\
\text { saliva mucus, membrane- } \\
\text { coating granules of buccal } \\
\text { mucosa }\end{array}$ & $\begin{array}{l}\text { NPs entrapped within solid lozenges, } \\
\text { chewing gum, flexible adhesive patches, } \\
\text { and viscous liquids to coat mucosa }\end{array}$ & & 125,126 \\
\hline \multirow[t]{4}{*}{ GIT } & $\begin{array}{l}\text { Tight junction barriers, } \\
\text { cell composition }\end{array}$ & $\begin{array}{l}\text { - Coating drug-loaded NPs with bacterial } \\
\text { invasive ligands to target M cell surface } \\
\text { components }\end{array}$ & $\begin{array}{l}\text { Receptor-mediated } \\
\text { endocytosis }\end{array}$ & 91,127 \\
\hline & Low $\mathrm{pH}$ gradients & $\begin{array}{l}\text { - } \mathrm{pH} \text {-sensitive cationic } 343 \mathrm{~nm} \\
\text { trimethylchitosan and } 212 \mathrm{~nm} \\
\text { PLGA-PEG mannose NPs }\end{array}$ & $\begin{array}{l}\text { Receptor-mediated } \\
\text { endocytosis }\end{array}$ & 90,128 \\
\hline & $\begin{array}{l}\text { Thick, anionic mucus } \\
\text { layer }\end{array}$ & $\begin{array}{l}\text { - I54 nm cationic poly-6-cationic } \\
\text { amphiphilic cyclodextrin-DNA complex } \\
\text { internalized by intestinal epithelial cells }\end{array}$ & Macropinocytosis & 129,130 \\
\hline & Macrophages & - Hydrophobic, neutral aminated NPs & Transcytosis & 131 \\
\hline \multirow[t]{6}{*}{ Lungs } & $\begin{array}{l}\text { Alveolar-capillary barrier, } \\
\text { complex tight junctions }\end{array}$ & - I5-100 nm gold NPs & Transcytosis & 132 \\
\hline & & $\begin{array}{l}\text { - Commercial multi-walled } \\
\text { carbon-NTs disrupt tight junctions }\end{array}$ & Paracellular & 133 \\
\hline & & - Hydrophilic, surfactant-coated, enzymatic & & 134 \\
\hline & & $\begin{array}{l}20 \mathrm{~nm} \text { PEI-PLGA NPs in } 1.6 \mu \mathrm{m} \text { microgel } \\
\text { - Discoidal-shaped NPs }\end{array}$ & & 59 \\
\hline & Alveolar lining fluid & $\begin{array}{l}\text { - } 200 \mathrm{~nm} \text { NPs complexed with Fc } \\
\text { portion of IgG }\end{array}$ & $\begin{array}{l}\text { Receptor-mediated } \\
\text { endocytosis }\end{array}$ & 135 \\
\hline & Macrophages & $\begin{array}{l}\text { - } 235 \mathrm{~nm} \text { protein-based NPs } \\
\text { (serum albumin and transferrin) }\end{array}$ & $\begin{array}{l}\text { Receptor-mediated } \\
\text { transcytosis }\end{array}$ & 4,134 \\
\hline \multirow[t]{3}{*}{ Kidney } & $\begin{array}{l}200-300 \mathrm{~nm} \text { thick } \\
\text { glycocalyx layer }\end{array}$ & - 78-100 nm spherical PLGA NPs & $\begin{array}{l}\text { Caveolae-mediated } \\
\text { endocytosis }\end{array}$ & 136,137 \\
\hline & $\begin{array}{l}\text { Phagocytic mesangial } \\
\text { cells }\end{array}$ & $\begin{array}{l}\text { - Albumin/streptavidin as ligands } \\
\text { targeting renal tubular cells }\end{array}$ & $\begin{array}{l}\text { Receptor-mediated } \\
\text { endocytosis }\end{array}$ & 138,139 \\
\hline & Cationic decomplexation & $\begin{array}{l}\text { - Anionic derivatives carboxylated, } \\
\text { co-dimethyl maleic acid, acetylated } \\
\text { low-molecular weight chitosan, or } \\
\text { PVP as NP coating }\end{array}$ & $\begin{array}{l}\text { Receptor-mediated } \\
\text { endocytosis }\end{array}$ & $\begin{array}{l}|40,| 4 \mid \\
142\end{array}$ \\
\hline
\end{tabular}

Abbreviations: AGP, alpha I-acid glycoprotein; BBB, blood-brain barrier; BSCB, blood-spinal cord barrier; BV, blood vessel; CPPs, cell-penetrating proteins or peptides; GIT, gastrointestinal tract; NP, nanoparticle; NT, nanotube; PEG, poly(ethylene glycol); PEl, polyethylenimine; PLGA, poly(lactic-co-glycolic acid); PVP, poly-vinyl pyyrolidone; SLN, solid lipid nanoparticle.

to the organelle level of therapeutics. By combining many physicochemical and mechanical NP parameters specific to certain cell types or organ systems, an optimal level of cellular uptake can be achieved. Research has specified several NP characteristics that are pertinent for efficient internalization; however, it is immensely limited on more detailed trans-barrier uptake kinetics that would crucially improve NP efficacy and intracellular targeting while maintaining stability and nontoxicity. Nano drug carriers can be greatly exploited provided ex vivo and in vivo research is extensively conducted.
Pertinent to the abovementioned NP factors, we need to understand that by optimizing NP parameters and characteristics that support internalization theories and studies for enhanced intracellular delivery, these designed systems may not promote optimal drug entrapment or have adequate drug release. The issue of drug delivery design can be addressed but other in vivo requirements such as adequate clearance from systemic circulation, release of drugs from nontargeted sites, drug release from the nanosystem, and elimination of the nanocarrier from the body need to be adhered to. As the knowledge of physicochemical and physiological in vivo 
processes improves, nanomedicine can be further specialized to attain the absolute effect intended.

\section{Disclosure}

The authors report no conflicts of interest in this work.

\section{References}

1. Alonso MJ. Nanomedicines for overcoming biological barriers. Biomed Pharmacother. 2004;58(3):168-172.

2. Gratton SE, Napier ME, Ropp PA, Tian S, DeSimone JM. Microfabricated particles for engineered drug therapies: elucidation into the mechanisms of cellular internalization of PRINT particles. Pharm Res. 2008;25(12):2845-2852.

3. Parveen S, Misra R, Sahoo SK. Nanoparticles: a boon to drug delivery, therapeutics, diagnostics and imaging. Nanomedicine. 2012;8(2) 147-166.

4. Brzoska M, Langer K, Coester C, Loitsch S, Wagner TO, Mallinckrodt C. Incorporation of biodegradable nanoparticles into human airway epithelium cells-in vitro study of the suitability as a vehicle for drug or gene delivery in pulmonary diseases. Biochem Biophys Res Commun 2004;318(2):562-570.

5. Kumari A, Yadav SK, Yadav SC. Biodegradable polymeric nanoparticles based drug delivery systems. Colloids Surf B Biointerfaces. 2010;75(1):1-18.

6. Xiang S, Tong H, Shi Q, et al. Uptake mechanisms of non-viral gene delivery. J Control Release. 2012;158(3):371-378.

7. Mousavi S, Malerd L, Berg T, Kjeken R. Clathrin-dependent endocytosis. Biochem J. 2004;377:1-16.

8. Xu S, Olenyuk BZ, Okamoto CT, Hamm-Alvarez SF. Targeting receptor-mediated endocytotic pathways with nanoparticles: rationale and advances. Adv Drug Deliv Rev. 2012;65(1):121-138.

9. Kumari S, Mg S, Mayor S. Endocytosis unplugged: multiple ways to enter the cell. Cell Res. 2010;20(3):256-275.

10. Pelkmans L, Püntener D, Helenius A. Local actin polymerization and dynamin recruitment in SV40-induced internalization of caveolae. Science. 2002;296(5567):535-539.

11. Wang Z, Tiruppathi C, Minshall RD, Malik AB. Size and dynamics of caveolae studied using nanoparticles in living endothelial cells. ACS Nano. 2009;3(12):4110-4116.

12. Sahay G, Alakhova DY, Kabanov AV. Endocytosis of nanomedicines. J Control Release. 2010;145(3):182-195.

13. Kerr MC, Teasdale RD. Defining macropinocytosis. Traffic. 2009; 10(4):364-371.

14. Hillaireau H, Couvreur P. Nanocarriers' entry into the cell: relevance to drug delivery. Cell Mol Life Sci. 2009;66(17):2873-2896.

15. Groves E, Dart A, Covarelli V, Caron E. Molecular mechanisms of phagocytic uptake in mammalian cells. Cell Mol Life Sci. 2008; 65(13):1957-1976.

16. Park H, Cox D. Cdc 42 regulates Fc $\gamma$ receptor-mediated phagocytosis through the activation and phosphorylation of Wiskott-Aldrich syndrome protein (WASP) and neural-WASP. Mol Biol Cell. 2009; 20(21):4500-4508.

17. Bomsel M, Prydz K, Parton RG, Gruenberg J, Simons K. Endocytosis in filter-grown Madin-Darby canine kidney cells. J Cell Biol. 1989;109(6):3243-3258

18. Gonzalez-Mariscal L, Hernández S, Vega J. Inventions designed to enhance drug delivery across epithelial and endothelial cells through the paracellular pathway. Recent Pat Drug Deliv Formul. 2008;2(2): 145-176.

19. Mostov KE. Transepithelial transport of immunoglobulins. Annu Rev Immunol. 1994;12(1):63-84.

20. Lu W, Xiong C, Zhang R, et al. Receptor-mediated transcytosis: a mechanism for active extravascular transport of nanoparticles in solid tumors. J Control Release. 2012;161(3):959-966.
21. Ferrati S, McConnell KI, Mack AC, et al. Cellular communication via nanoparticle-transporting biovesicles. Nanomedicine (Lond). 2014; 9(5):581-592.

22. Hayashi M, Tomita M, Awazu S. Transcellular and paracellular contribution to transport processes in the colorectal route. Adv Drug Deliv Rev. 1997;28(2):191-204.

23. Salamat-Miller N, Johnston TP. Current strategies used to enhance the paracellular transport of therapeutic polypeptides across the intestinal epithelium. Int J Pharm. 2005;294(1):201-216.

24. Mohanraj V, Chen Y. Nanoparticles - a review. Trop J Pharm Res. 2007;5(1):561-573.

25. Reddy ST, Berk DA, Jain RK, Swartz MA. A sensitive in vivo model for quantifying interstitial convective transport of injected macromolecules and nanoparticles. $J$ Appl Physiol (1985). 2006;101(4):1162-1169.

26. Moghimi SM, Hunter AC, Andresen TL. Factors controlling nanoparticle pharmacokinetics: an integrated analysis and perspective. Annu Rev Pharmacol Toxicol. 2012;52:481-503.

27. Barua S, Rege, K. Cancer-cell-phenotype-dependent differential intracellular trafficking of unconjugated quantum dots. Small. 2009; 5(3):370-376

28. Snijder B, Sacher R, Rämö P, Damm EM, Liberali P, Pelkmans L. Population context determines cell-to-cell variability in endocytosis and virus infection. Nature. 2009;461(7263):520-523.

29. Aggarwal P, Hall JB, McLeland CB, Dobrovolskaia MA, McNeil SE. Nanoparticle interaction with plasma proteins as it relates to particle biodistribution, biocompatibility and therapeutic efficacy. Adv Drug Deliv Rev. 2009;61(6):428-437.

30. Gunaseelan S, Gunaseelan K, Deshmukh M, Zhang X, Sinko PJ. Surface modifications of nanocarriers for effective intracellular delivery of anti-HIV drugs. Adv Drug Deliv Rev. 2010;62(4):518-531.

31. Torrano AA, Blechinger J, Osseforth C, et al. A fast analysis method to quantify nanoparticle uptake on a single cell level. Nanomedicine (Lond). 2013;8(11):1815-1828.

32. Luo Y, Chen D, Ren L, Zhao X, Qin J. Solid lipid nanoparticles for enhancing vinpocetine's oral bioavailability. $J$ Control Release. 2006;114(1):53-59.

33. des Rieux A, Fievez V, Garinot M, Schneider Y, Préat V. Nanoparticles as potential oral delivery systems of proteins and vaccines: a mechanistic approach. J Control Release. 2006;116(1):1-27.

34. Acosta E. Bioavailability of nanoparticles in nutrient and nutraceutical delivery. Curr Opin Colloid Interface Sci. 2009;14(1):3-15.

35. Patel NR, Damann K, Leonardi C, Sabliov CM. Size dependency of PLGA-nanoparticle uptake and antifungal activity against Aspergillus flavus. Nanomedicine (Lond). 2011;6(8):1381-1395.

36. Chithrani BD, Ghazani AA, Chan WC. Determining the size and shape dependence of gold nanoparticle uptake into mammalian cells. Nano Lett. 2006;6(4):662-668.

37. Jin H, Heller DA, Sharma R, Strano MS. Size-dependent cellular uptake and expulsion of single-walled carbon nanotubes: single particle tracking and a generic uptake model for nanoparticles. ACS Nano. 2009;3(1):149-158.

38. Awaad A, Nakamura M, Ishimura K. Imaging of size-dependent uptake and identification of novel pathways in mouse Peyer's patches using fluorescent organosilica particles. Nanomedicine. 2012;8(5):627-636.

39. Roger E, Lagarce F, Garcion E, Benoit J. Lipid nanocarriers improve paclitaxel transport throughout human intestinal epithelial cells by using vesicle-mediated transcytosis. J Control Release. 2009;140(2): 174-181.

40. Torchilin VP. Recent approaches to intracellular delivery of drugs and DNA and organelle targeting. Annu Rev Biomed Eng. 2006;8: 343-375.

41. Nicolete R, Dos Santos DF, Faccioli LH. The uptake of PLGA micro or nanoparticles by macrophages provokes distinct in vitro inflammatory response. Int Immunopharmacol. 2011;11(10):1557-1563.

42. Loh JW, Saunders M, Lim LY. Cytotoxicity of monodispersed chitosan nanoparticles against the Caco-2 cells. Toxicol Appl Pharmacol. 2012;262(3):273-282. 
43. Harush-Frenkel O, Rozentur E, Benita S, Altschuler Y. Surface charge of nanoparticles determines their endocytic and transcytotic pathway in polarized MDCK cells. Biomacromolecules. 2008;9(2):435-443.

44. Nan A, Bai X, Son SJ, Lee SB, Ghandehari H. Cellular uptake and cytotoxicity of silica nanotubes. Nano Lett. 2008;8(8):2150-2154.

45. Ilina P, Hyvonen Z, Saura M, Sandvig K, Yliperttula M, Ruponen M. Genetic block of endocytic pathways reveals differences in the intracellular processing of non-viral gene delivery systems. J Control Release. 2012;163(3):385-395.

46. Rand RP. Interacting phospholipid bilayers: measured forces and induced structural changes. Annu Rev Biophys Bioeng. 1981;10:277-314.

47. Jallouli Y, Paillard A, Chang J, Sevin E, Betbeder D. Influence of surface charge and inner composition of porous nanoparticles to cross blood-brain barrier in vitro. Int J Pharm. 2007;344(1-2):103-109.

48. Karlsson J, Ungell A, Gråsjö J, Artursson P. Paracellular drug transport across intestinal epithelia: influence of charge and induced water flux. Eur J Pharm Sci. 1999;9(1):47-56.

49. Lin IC, Liang M, Liu TY, Monteiro MJ, Toth I. Cellular transport pathways of polymer coated gold nanoparticles. Nanomedicine. 2012; 8(1):8-11.

50. Zhang LW, Monteiro-Riviere NA. Mechanisms of quantum dot nanoparticle cellular uptake. Toxicol Sci. 2009;110(1):138-155.

51. Muthu MS, Singh S. Studies on biodegradable polymeric nanoparticles of risperidone: in vitro and in vivo evaluation. Nanomedicine (Lond). 2008;3(3):305-319.

52. Champion JA, Katare YK, Mitragotri S. Making polymeric micro-and nanoparticles of complex shapes. Proc Natl Acad Sci U S A. 2007; 104(29):11901-11904.

53. Hao N, Li L, Zhang Q, et al. The shape effect of PEGylated mesoporous silica nanoparticles on cellular uptake pathway in Hela cells. Microporous Mesoporous Mater. 2012;162:14-23.

54. Han Y, Alsayed A, Nobili M, Zhang J, Lubensky TC, Yodh AG. Brownian motion of an ellipsoid. Science. 2006;314(5799):626-630.

55. Champion JA, Mitragotri S. Role of target geometry in phagocytosis. Proc Natl Acad Sci US A. 2006;103(13):4930-4934.

56. Yang K, Ma YQ. Computer simulation of the translocation of nanoparticles with different shapes across a lipid bilayer. Nat Nanotechnol. 2010;5(8):579-583.

57. Gratton SE, Ropp PA, Pohlhaus PD. The effect of particle design on cellular internalization pathways. Proc Natl Acad Sci USA. 2008;105(33):11613-11618.

58. Sadeghi B, Garmaroudi FS, Hashemi M, et al. Comparison of the antibacterial activity on the nanosilver shapes: nanoparticles, nanorods and nanoplates. Adv Powder Technol. 2012;23(1):22-26.

59. Decuzzi P, Godin B, Tanaka T, et al. Size and shape effects in the biodistribution of intravascularly injected particles. J Control Release. 2010;141(3):320-327.

60. Park JH, von Maltzahn G, Zhang L, et al. Systematic surface engineering of magnetic nanoworms for in vivo tumor targeting. Small. 2009;5(6):694-700.

61. Devarajan PV, Jindal AB, Patil RR, Mulla F, Gaikwad RV, Samad A. Particle shape: a new design parameter for passive targeting in splenotropic drug delivery. J Pharm Sci. 2010;99(6):2576-2581.

62. Naahidi S, Jafari M, Edalat F, Raymond K, Khademhosseini A, Chen P. Biocompatibility of engineered nanoparticles for drug delivery. J Control Release. 2012;166(2):182-194.

63. Howard KA, Peer D. Providing the full picture: a mandate for standardizing nanoparticle-based drug delivery. Nanomedicine (Lond). 2013;8(7):1031-1033

64. Dobrovolskaia MA, McNeil SE. Immunological properties of engineered nanomaterials. Nat Nanotechnol. 2077;2(8):469-478.

65. Owens DE 3rd, Peppas NA. Opsonization, biodistribution, and pharmacokinetics of polymeric nanoparticles. Int J Pharm. 2006;307(1): 93-102.

66. Chiu YL, Ho YC, Chen YM, et al. The characteristics, cellular uptake and intracellular trafficking of nanoparticles made of hydrophobicallymodified chitosan. J Control Release. 2010;146(1):152-159.
67. Brigger I, Dubernet C, Couvreur P. Nanoparticles in cancer therapy and diagnosis. Adv Drug Deliv Rev. 2002;54(5):631-651.

68. Gomes-da-Silva LC, Fernández Y, Abasolo I, et al. Efficient intracellular delivery of siRNA with a safe multitargeted lipid-based nanoplatform. Nanomedicine (Lond). 2013;8(9):1397-1413.

69. Sonaje K, Lin KJ, Tseng MT, et al. Effects of chitosan-nanoparticlemediated tight junction opening on the oral absorption of endotoxins. Biomaterials. 2011;32(33):8712-8721.

70. Sambruy Y, Ferruzza S, Ranaldi G, De Angelis I. Intestinal cell culture models: applications in toxicology and pharmacology. Cell Biol Toxicol. 2001;17(4-5):301-317.

71. Luk BT, Hu CM, Fang RH, et al. Interfacial interactions between natural RBC membranes and synthetic polymeric nanoparticles. Nanoscale. 2014;6(5):2730-2737.

72. Lin TY, Li YP, Zhang $\mathrm{H}$, et al. Tumor-targeting multifunctional micelles for imaging and chemotherapy of advanced bladder cancer. Nanomedicine (Lond). 2013;8(8):1239-1251.

73. Loureiro JA, Gomes B, Coelho MA, Carmo Pereira MD, Rocha S. Targeting nanoparticles across the blood-brain barrier with monoclonal antibodies. Nanomedicine (Lond). 2014;9(5):709-722.

74. Patel LN, Zaro JL, Shen W. Cell penetrating peptides: intracellular pathways and pharmaceutical perspectives. Pharm Res. 2077;24(11):1977-1992.

75. Jones AT. Gateways and tools for drug delivery: endocytic pathways and the cellular dynamics of cell penetrating peptides. Int J Pharm. 2008;354(1-2):34-38.

76. Bareford LM, Swaan PW. Endocytic mechanisms for targeted drug delivery. Adv Drug Deliv Rev. 2007;59(8):748-758.

77. Pujals S, Giralt E. Proline-rich, amphipathic cell-penetrating peptides. Adv Drug Deliv Rev. 2008;60(4-5):473-484.

78. Oh P, Borgström $\mathrm{P}$, Witkiewicz $\mathrm{H}$, et al. Live dynamic imaging of caveolae pumping targeted antibody rapidly and specifically across endothelium in the lung. Nat Biotechnol. 2007;25(3):327-337.

79. Oba M, Aoyagi K, Miyata K, et al. Polyplex micelles with cyclic RGD peptide ligands and disulfide cross-links directing to the enhanced transfection via controlled intracellular trafficking. Mol Pharm. 2008;5(6):1080-1092.

80. Liu J, Kopecková P, Bühler P, et al. Biorecognition and subcellular trafficking of HPMA copolymer-anti-PSMA antibody conjugates by prostate cancer cells. Mol Pharm. 2009;6(3):959-970.

81. Sahoo SK, Ma W, Labhasetwar V. Efficacy of transferrin-conjugated paclitaxel-loaded nanoparticles in a murine model of prostate cancer. Int J Cancer. 2004;112(2):335-340.

82. Kocbek P, Obermajer N, Cegnar M, Kos J, Kristl J. Targeting cancer cells using PLGA nanoparticles surface modified with monoclonal antibody. J Control Release. 2007;120(1):18-26.

83. Huang $X$, Peng $X$, Wang $Y$. A reexamination of active and passive tumor targeting by using rod-shaped gold nanocrystals and covalently conjugated peptide ligands. ACS Nano. 2010;4(10):5887-5896.

84. Temsamani J, Vidal P. The use of cell-penetrating peptides for drug delivery. Drug Discov Today. 2004;9(23):1012-1019.

85. Patel PC, Giljohann DA, Daniel WL, Zheng D, Prigodich AE, Mirkin CA. Scavenger receptors mediate cellular uptake of polyvalent oligonucleotide-functionalized gold nanoparticles. Bioconjug Chem. 2010;21(12):2250-2256.

86. Liu Y, Shipton MK, Ryan J, et al. Synthesis, stability, and cellular internalization of gold nanoparticles containing mixed peptide-poly(ethylene glycol) monolayers. Anal Chem. 2007;79(6):2221-2229.

87. Fortier C, Durocher Y, De Crescenzo G. Surface modification of nonviral nanocarriers for enhanced gene delivery. Nanomedicine (Lond). 2014;9(1):135-151.

88. Brannon-Peppas L, Blanchette JO. Nanoparticle and targeted systems for cancer therapy. Adv Drug Deliv Rev. 2004;56(11):1649-1659.

89. Vllasaliu D, Fowler R, Garnett M, Eaton M, Stolnik S. Barrier characteristics of epithelial cultures modelling the airway and intestinal mucosa: a comparison. Biochem Biophys Res Commun. 2011;415(4): 579-585. 
90. Ferrari M. Frontiers in cancer nanomedicine: directing mass transport through biological barriers. Trends Biotechnol. 2010;28(4): 181-188.

91. Masaoka Y, Tanaka Y, Kataoka M, Sakuma S, Yamashita S. Site of drug absorption after oral administration: assessment of membrane permeability and luminal concentration of drugs in each segment of gastrointestinal tract. Eur J Pharm Sci. 2006;29(3-4):240-250.

92. Kuo TR, Wu CL, Hsu CT, et al. Chemical enhancer induced changes in the mechanisms of transdermal delivery of zinc oxide nanoparticles. Biomaterials. 2009;30(16):3002-3008.

93. Chen-yu G, Chun-fen Y, Qi-lu L, et al. Development of a quercetinloaded nanostructured lipid carrier formulation for topical delivery. Int J Pharm. 2012;430(1-2):292-298.

94. Baroli B, Ennas MG, Loffredo F, Isola M, Pinna R, López-Quintela MA. Penetration of metallic nanoparticles in human full-thickness skin. J Invest Dermatol. 2007;127(7):1701-1712.

95. Shim J, Seok Kang H, Park WS, Han SH, Kim J, Chang IS. Transdermal delivery of mixnoxidil with block copolymer nanoparticles. J Control Release. 2004;97(3):477-484.

96. Ryman-Rasmussen JP, Riviere JE, Monteiro-Riviere NA. Penetration of intact skin by quantum dots with diverse physicochemical properties. Toxicol Sci. 2006;91(1):159-165.

97. Wang J, Chen J, Ye N, et al. Absorption, pharmacokinetics and disposition properties of solid lipid nanoparticles (SLNs). Curr Drug Metab. 2012;13(4):447-456.

98. Ting SR, Whitelock JM, Tomic R, et al. Cellular uptake and activity of heparin functionalised cerium oxide nanoparticles in monocytes. Biomaterials. 2013;34(17):4377-4386.

99. Gupta H, Aqil M, Khar RK, Ali A, Bhatnagar A, Mittal G. Sparfloxacin-loaded PLGA nanoparticles for sustained ocular drug delivery. Nanomedicine. 2010;6(2):324-333.

100. Freddo TF. A contemporary concept of the blood-aqueous barrier. Prog Retin Eye Res. 2012;32:181-195.

101. Guinedi AS, Mortada ND, Mansour S, Hathout RM. Preparation and evaluation of reverse-phase evaporation and multilamellar niosomes as ophthalmic carriers of acetazolamide. Int J Pharm. 2005;306(1-2):71-82.

102. de la Fuente M, Raviña M, Paolicelli P, Sanchez A, Seijo B, Alonso MJ. Chitosan-based nanostructures: a delivery platform for ocular therapeutics. Adv Drug Deliv Rev. 2010;62(1):100-117.

103. Mautes AE, Weinzierl MR, Donovan F, Noble LJ. Vascular events after spinal cord injury: contribution to secondary pathogenesis. Phys Ther. 2000;80(7):673-687.

104. Das M, Patil S, Bhargava N. Auto-catalytic ceria nanoparticles offer neuroprotection to adult rat spinal cord neurons. Biomaterials. 2007; 28(10):1918-1925.

105. Garcia-Garcia E, Andrieux K, Gil S, et al. A methodology to study intracellular distribution of nanoparticles in brain endothelial cells. Int J Pharm. 2005;298(2):310-314.

106. Costantino L, Boraschi D. Is there a clinical future for polymeric nanoparticles as brain-targeting drug delivery agents? Drug Discov Today. 2012;17(7):367-378.

107. Hynynen K. Ultrasound for drug and gene delivery to the brain. $A d v$ Drug Deliv Rev. 2008;60(10):1209-1217.

108. Stam R. Electromagnetic fields and the blood-brain barrier. Brain Res Rev. 2010;65(1):80-97.

109. Reid DM, Perry VH, Andersson PB, Gordon S. Mitosis and apoptosis of microglia in vivo induced by an anti-CR3 antibody which crosses the blood-brain barrier. Neuroscience. 1993;56(3):529-533.

110. Kuo YC, Lee CL. Methylmethacrylate-sulfopropylmethacrylate nanoparticles with surface RMP-7 for targeting delivery of antiretroviral drugs across the blood-brain barrier. Colloids Surf B Biointerfaces. 2012;90:75-82.

111. Dhanikula RS, Argaw A, Bouchard J, Hildgen P. Methotrexate loaded polyether-copolyester dendrimers for the treatment of gliomas: enhanced efficacy and intratumoral transport capability. Mol Pharm. 2008;5(1):105-116.
112. Pang Z, Gao H, Yu Y, et al. Brain delivery and cellular internalization mechanisms for transferrin conjugated biodegradable polymersomes. Int J Pharm. 2011;415(1):284-292.

113. Martins S, Tho I, Reimold I, et al. Brain delivery of camptothecin by means of solid lipid nanoparticles: formulation design, in vitro and in vivo studies. Int J Pharm. 2012;439(1-2):49-62.

114. Wen CJ, Yen TC, Al-Suwayeh SA, Chang HW, Fang JY. In vivo realtime fluorescence visualization and brain-targeting mechanisms of lipid nanocarriers with different fatty ester: oil ratios. Nanomedicine (Lond). 2011;6(9):1545-1559.

115. Thorne RG, Nicholson C. In vivo diffusion analysis with quantum dots and dextrans predicts the width of brain extracellular space. Proc Natl Acad Sci U S A. 2006;103(14):5567-5572.

116. Zhang X, Chen G, Wen L, et al. Novel multiple agents loaded PLGA nanoparticles for brain delivery via inner ear administration: in vitro and in vivo evaluation. Eur J Pharm Sci. 2013;48(4-5):595-603.

117. Mistry A, Stolnik S, Illum L. Nanoparticles for direct nose-to-brain delivery of drugs. Int J Pharm. 2009;379(1):146-157.

118. Geng Y, Dalhaimer P, Cai S, et al. Shape effects of filaments versus spherical particles in flow and drug delivery. Nat Nanotechnol. 2007;2(4):249-255.

119. Jacobs F, Wisse E, De Geest B. The role of liver sinusoidal cells in hepatocyte-directed gene transfer. Am J Pathol. 2010;176(1):14-21.

120. Johnston HJ, Semmler-Behnke M, Brown DM, Kreyling W, Tran L, Stone V. Evaluating the uptake and intracellular fate of polystyrene nanoparticles by primary and hepatocyte cell lines in vitro. Toxicol Appl Pharmacol. 2010;242(1):66-78.

121. Lin A, Liu Y, Huang Y, et al. Glycyrrhizin surface-modified chitosan nanoparticles for hepatocyte-targeted delivery. Int J Pharm. 2008;359(1):247-253.

122. Kim TH, Park IK, Nah JW, Choi YJ, Cho CS. Galactosylated chitosan/ DNA nanoparticles prepared using water-soluble chitosan as a gene carrier. Biomaterials. 2004;25(17):3783-3792.

123. Doshi N, Mitragotri S. Macrophages recognize size and shape of their targets. PLoS One. 2010;5(4):e10051.

124. Lai SK, Wang YY, Hanes J. Mucus-penetrating nanoparticles for drug and gene delivery to mucosal tissues. Adv Drug Deliv Rev. 2009;61(2):158-171.

125. Madhav NV, Shakya AK, Shakya P, Singh K. Orotransmucosal drug delivery systems: a review. J Control Release. 2009;140(1-2):2-11.

126. Teubl BJ, Absenger M, Fröhlich E, Leitinger G, Zimmer A, Roblegg E. The oral cavity as a biological barrier system: design of an advanced buccal in vitro permeability model. Eur J Pharm Biopharm. 2013;84(2):386-393.

127. Kochut A, Dersch P. Bacterial invasion factors: tools for crossing biological barriers and drug delivery? Eur J Pharm Biopharm. 2013;84(2):242-250.

128. Coco R, Plapied L, Pourcelle V, et al. Drug delivery to inflamed colon by nanoparticles: comparison of different strategies. Int J Pharm. 2012;440(1):3-12.

129. Yang M, Lai SK, Wang YY, et al. Biodegradable nanoparticles composed entirely of safe materials that rapidly penetrate human mucus. Angew Chem Int Ed Engl. 2011;50(11):2597-2600.

130. O’Neill MJ, Guo J, Byrne C, Darcy R, O’Driscoll CM. Mechanistic studies on the uptake and intracellular trafficking of novel cyclodextrin transfection complexes by intestinal epithelial cells. Int J Pharm. 2011;413(1-2):174-183.

131. des Rieux A, Ragnarsson EG, Gullberg E, Préat V, Schneider YJ, Artursson P. Transport of nanoparticles across an in vitro model of the human intestinal follicle associated epithelium. Eur J Pharm Sci. 2055;25(4):455-465.

132. Brandenberger C, Rothen-Rutishauser B, Mühlfeld C, et al. Effects and uptake of gold nanoparticles deposited at the air-liquid interface of a human epithelial airway model. Toxicol Appl Pharmacol. 2010;242(1):56-65.

133. Rotoli BM, Bussolati O, Bianchi MG, et al. Non-functionalized multiwalled carbon nanotubes alter the paracellular permeability of human airway epithelial cells. Toxicol Lett. 2008;178(2):95-102. 
134. Wanakule P, Liu GW, Fleury AT, Roy K. Nano-inside-micro: disease-responsive microgels with encapsulated nanoparticles for intracellular drug delivery to the deep lung. J Control Release. 2012; 162(2):429-437.

135. Vllasaliu D, Alexander C, Garnett M, Eaton M, Stolnik S. Fc-mediated transport of nanoparticles across airway epithelial cell layers. J Control Release. 2012;158(3):479-486.

136. Haraldsson B, Nyström J, Deen WM. Properties of the glomerular barrier and mechanisms of proteinuria. Physiol Rev. 2008;88(2): 451-487.

137. He B, Jia Z, Du W. The transport pathways of polymer nanoparticles in MDCK epithelial cells. Biomaterials. 2013;34(17):4309-4326.

138. Christensen EI, Verroust PJ, Nielsen R. Receptor-mediated endocytosis in renal proximal tubule. Pflugers Arch. 2009;458(6):1039-1048.

139. Bertrand N, Leroux JC. The journey of a drug-carrier in the body: an anatomo-physiological perspective. J Control Release. 2012; 161(2):152-163.
140. Kodaira H, Tsutsumi Y, Yoshioka Y, et al. The targeting of anionized polyvinylpyrrolidone to the renal system. Biomaterials. 2004; 25(18):4309-4315.

141. Yamamoto Y, Tsutsumi Y, Yoshioka Y, et al. Poly(vinylpyrrolidoneco-dimethyl maleic acid) as a novel renal targeting carrier. J Control Release. 2004;95(2):229-237.

142. Yuan ZX, Zhang ZR, Zhu D, et al. Specific renal uptake of randomly $50 \% \mathrm{~N}$-acetylated low molecular weight chitosan. Mol Pharm. 2008;6(1):305-314.

143. Narayanan K, Yen SK, Dou Q, et al. Mimicking cellular transport mechanism in stem cells through endosomal escape of new peptidecoated quantum dots. Sci Rep. 2013;3:2184.

144. Tkachenko AG, Xie H, Coleman D, et al. Multifunctional gold nanoparticle-peptide complexes for nuclear targeting. J Am Chem Soc. 2003;125(16):4700-4701.

145. Chen J,WuC,OupickýD. Bioreduciblehyperbranched poly(amidoamine)s for gene delivery. Biomacromolecules. 2009;10(10):2921-2927.

\section{Publish your work in this journal}

The International Journal of Nanomedicine is an international, peerreviewed journal focusing on the application of nanotechnology in diagnostics, therapeutics, and drug delivery systems throughout the biomedical field. This journal is indexed on PubMed Central, MedLine, CAS, SciSearch ${ }^{\circledR}$, Current Contents ${ }^{\circledR} /$ Clinical Medicine,
Journal Citation Reports/Science Edition, EMBase, Scopus and the Elsevier Bibliographic databases. The manuscript management system is completely online and includes a very quick and fair peer-review system, which is all easy to use. Visit http://www.dovepress.com/ testimonials.php to read real quotes from published authors. 